УДК 658:336:351

Lipych Lubov,

Doctor of Economics, professor,

Lesya Ukrainka Eastern European National University, Department of Economics, Security and Innovation of the Enterprise;

Lutsk, ORCID ID 0000-0002-9059-7271, e-mail: lglipych@gmail.com

Skoruk Olena, PhD in Economics, Associate Professor, Lesya Ukrainka Eastern European National University, Department of Economics, Security and Innovation of the Enterprise, Lutsk, ORCID ID 0000-0002-9497-1945, e-mail: Skoruklena@gmail.com

https://doi.org/10.29038/2411-4014-2020-03-106-113

\title{
PROVIDING FINANCIAL AND ECONOMIC SECURITY OF THE ENTERPRISE IN THE CONDITIONS OF DEVELOPMENT OF THE DIGITAL ECONOMY
}

The article clarifies the essence and features of the digital economy. It was found (according to the European Commission) that Denmark, Sweden and Finland have taken the lead in the digital economy over the last three years; the lowest level of digitization is in Bulgaria, Romania and Greece. The necessity of development and introduction of the system of financial and economic security of the enterprise in the conditions of development of digital economy is substantiated. The essence of the concept of financial and economic security of the enterprise in the conditions of digitalization as protection of activity of the enterprise from external and internal negative factors and introduction of innovative information technologies and software for the purpose of its stable and dynamic development is defined. The priority directions of ensuring the financial and economic security of enterprises in the new realities of digitalization of economic activity are given.

Key words: digital technologies, digital economy, financial and economic security, information security, information.

Липыч Любовь, доктор экономических наук, профессор, Восточноевропейский национальный университет имени Леси Украинки, кафедра экономики, безопасности и инновационной деятельности предприятия, г. Луцк

Скорук Елена, кандидат экономических наук, доцент, Восточноевропейский национальный университет имени Леси Украинки, кафедра экономики, безопасности и инновационной деятельности предприятия, г. Луцк

\section{ОБЕСПЕЧЕНИЕ ФИНАНСОВО-ЭКОНОМИЧЕСКОЙ БЕЗОПАСНОСТИ ПРЕДПРИЯТИЯ В УСЛОВИЯХ РАЗВИТИЯ ЦИФРОВОЙ ЭКОНОМИКИ}

В статье выяснили сущность и особенности формирования цифровой экономики. Установили (по данным Европейской комиссии), что лидерские позиции по уровню цифровой экономики за последние три года заняли Дания, Швеция и Финляндия; низкий уровень цифровизации в Болгарии, Румынии и Греции. Обоснована необходимость разработки и внедрения системы финансово-экономической безопасности предприятия в условиях развития цифровой экономики. Определена сущность понятия финансово-экономической безопасности предприятия в условиях цифровизации как защищенность деятельности предприятия от внешних и внутренних негативных факторов и внедрение инновационных информационных технологий и программных средств с целью его стабильного и динамичного развития. Приведены приоритетные направления обеспечения 
финансово-экономической безопасности предприятий в новых реалиях диджитализации хозяйственной деятельности.

Ключевые слова: цифровые технологии, цифровая экономика, финансово-экономическая безопасность, информационная безопасность, информация.

Ліпич Любов, доктор економічних наук, професор, Східносвропейський національний університет імені Лесі Українки, кафедра економіки, безпеки та інноваційної діяльності підприємства, м. Луцьк

Скорук Олена, кандидат економічних наук, доцент, Східносвропейський національний університет імені Лесі Українки, кафедра економіки, безпеки та інноваційної діяльності підприємства,

м. Луцьк

\section{ЗАБЕЗПЕЧЕННЯ ФІНАНСОВО-ЕКОНОМІЧНОЇ БЕЗПЕКИ ПІДПРИЕМСТВА В УМОВАХ РОЗВИТКУ ЦИФРОВОї ЕКОНОМІКИ}

У статті 3'ясовано, що значну роль у розвитку всіх сфер суспільства відіграють інноваційні інформаційні та комп'ютерні технології, які є основою цифрової економіки. Особливо вагомий вплив здійснюють процеси цифровізації на господарську діяльність суб'сктів господарювання, а, отже, й на забезпечення їхньої фінансово-економічної безпеки.

Мета статті - визначення особливостей забезпечення фінансово-економічної безпеки вітчизняних підприємств в умовах розвитку цифрової економіки. Для досягнення поставленої мети передбачено виконати такі завдання: з'ясувати сутність поняття «цифрова економіка», розглянути вплив цифрової економіки на діяльність підприємств та визначити особливості їх функціонування; виокремити загрози фінансовоекономічній безпеці підприємства під впливом цифровізації та визначити пріоритетні напрями забезпечення фінансово-економічної безпеки підприємств в умовах розвитку цифрової економіки.

3'ясовано, що єдиного підходу до визначення сутності поняття “цифрова економіка» не існує, як серед зарубіжних науковців, так і серед вітчизняних учених. Виникнення та розвиток цього поняття пов’язане 3 упровадженням в різні сфери життєдіяльності суспільства цифрових технологій.

Встановлено (за даними Європейської комісії), що лідерські позиції стосовно рівня цифрової економіки за останні три роки посіли Данія, Швеція та Фінляндія; найнижчий рівень цифровізації у Болгарії, Румунії та Греції.

Визначено основні загрози діяльності підприємств за умов цифрової економіки. Обгрунтовано необхідність розробки та впровадження системи фінансово-економічної безпеки підприємства в умовах розвитку цифрової економіки. Визначено сутність поняття фінансово-економічної безпеки підприємства в умовах цифровізації та наведено пріоритетні напрями забезпечення фінансово-економічної безпеки підприємств у нових реаліях діджиталізації господарської діяльності.

Отже, цифровізація стала невід'ємною складовою функціонування вітчизняних підприємств. Тому важливо швидше адаптовувати найкращі практики цифрової трансформації до розвитку вітчизняного бізнесу.

Ключові слова: цифрові технології, цифрова економіка, фінансово-економічна безпека, інформаційна безпека, інформація.

Formulation of the scientific problem and its significance. Nowadays, innovative information and computer technologies, which are the basis of the digital economy, play a significant role in the development of all aspects of society. The processes of digitalization have a particularly significant impact on the economic activities of economic entities, and consequently, on ensuring their financial and economic security. Therefore, the study of the peculiarities on the functioning of enterprises and ensuring their financial and economic security in the introduction of digital technologies is relevant.

Analysis of recent research and publications. The formation and development of the digital economy and its impact on socio-economic processes have been studied by such scientists as I. Ansoff, R. Ackoff, 
S. N. Bruskin， S. M. Veretyuk， V. Heyets， O. YE. Hudz， O. V. Kitova， A. M. Kozyryev， N. Lane, L. Gh. Lipych, T. Mesenbourg, D. Tapscott and others. Some aspects of financial and economic security of enterprises under the influence of digitalization of the economy were considered in the works of O. V. Arefyev, K. S. Horyachev, S. M. Ilyashenko, I. V. Sadchykova, S. M. Shkarlet etc. Despite a significant amount of work in the field of formation and development of the digital economy, further research of theoretical, methodological and applied aspect are neeeded to ensure financial and economic security of the enterprise in the context of digitalization.

The purpose and objectives of the article. The purpose of the article is to determine the features of financial and economic security of domestic enterprises in the growing digital economy. To achieve this goal it is planned to solve the following tasks: to clarify the essence of the concept of «digital economy», to consider the impact of the digital economy on the activities of enterprises and to determine the features of their functioning; to identify threats to the financial and economic security of the enterprise under the influence of digitalization and to identify priority areas for financial and economic security of enterprises in the conditions of developing digital economy.

Presentation of the main material and substantiation of the results of the research. The concept of digital economy was first proposed by Canadian economist and business consultant Don Tapscott in his work «Digital Economy: Promise and Peril in the Age of Networked Intelligence» [1]. The manuscript of the book was prepared in 1994, but the book itself was published later. However, the date of publication of the book as well as the term "digital economy" is considered to be 1994. Unfortunately, the author does not give a definition of «digital economy» in his work, but uses the concept of «Age of Networked Intelligence» and explains the changes in business in accordance with changes in digital technology. In 2014, a new edition of D. Tapscott [2] was published on the twentieth anniversary of writing the original version (1994) and the emergence of the term «digital economy». Many scholars still consider Don Tapscott to be one of the world's greatest «cyber gurus».

N. Lane in his work «Advancing the Digital Economy into the 21st Century» defines the digital economy as the convergence of computer and communication technologies on the Internet, which stimulate the development of e-commerce and large-scale changes in organizational structure [3], i.e. the author focuses on e-commerce. The term «e-commerce» is also used by Thomas Mesenbourg [4]. The author explains that the digital economy consists of the following components:

- e-business infrastructure (equipment; software; telecommunications; networks; buildings where digital economy items are created; support services, etc.) used for e-transactions and e-commerce;

- e-business, i.e any process that the company carries out using computer networks;

- e-commerce, the sale of goods through computer networks.

Thus, the most common definition of the digital economy is that it is a type of commercial activity related to the sale of goods and services through e-commerce. According to this understanding, the digital economy is an activity directly related to e-commerce, which includes: services related to online services, online stores, information sites that earn on advertising, and other activities.

Russian scientists understand the «digital economy» as any economic activity based on the use of digital technologies [5, p.13].

On the other hand, the «digital economy» is an economy based on new methods of generating, processing, storing, transmitting data, and digital computer technology. The core technologies of the digital economy are big data (the data itself and methods of working with them), artificial intelligence, blockchain technology, cloud computing, quantum technology, robotics, virtual reality, and others.

Among Ukrainian scientists, there are also different interpretations of the concept of «digital economy». In particular, S. M. Veretjuk and V. V. Pilinsjkyj defined the digital economy as an unrealized transformation of all spheres of the economy due to the transfer of all information resources and knowledge to a computer platform [6, p. 51]. S. V. Koljadenko considers the digital economy as one based on the production of electronic goods and services by high-tech business structures and the distribution of these products through e-commerce [7, p.106]. A. A. Apaljkova notes that the digital economy is the most important engine of innovation, competitiveness and economic development [8, p. 13].

Gh. Gh. Chmeruk notes that the digital economy is a separate sector of the economy in which economic activity is carried out by economic entities through the use of information and communication and digital 
technologies, where the main means (factors) of production are digital (electronic, virtual) data ( both numerical and textual) [9, p. 95].

Thus, a review of the above approaches to defining the essence of the digital economy led to the conclusion that the emergence and development of this concept is associated with the introduction of digital technologies in various spheres of society.

The Concept of Development of the Digital Economy and Society of Ukraine for 2018-2020 states that the digital economy means an activity in which the main means (factors) of production are digital (electronic, virtual) data, both numerical and textual [10]. This definition is considered official in Ukraine.

Thus, there is no single approach to defining the essence of this concept, both among foreign scientists and among Ukrainian scientists. Some talk about the digital economy in a narrow sense, identifying it directly with the computer industry and e-business, such as the well-known AliExpress. Another group of researchers identifies the digital economy with a separate area of scientific knowledge related to the economic theory of the information society. The third group perceives the digital economy as a special way of information society, the characteristic feature of which is the important role of intellectual creativity and information products.

Today, the digital economy has developed most in the world's leading countries. The McKinsey Institute estimates the share of the digital economy in the GDP of the EU $-8.2 \%$, the US and China - 10\%, Russia $-3.9 \%$, believing that by 2025 the digital economy will triple and will add from $20 \%$ to $34 \%$ of the contribution to GDP growth [11].

The digital economy in many countries is assessed using digital economy indices, which are used to determine country ratings and the level of international digitization. Among such indices:

- Digital Economy and society index - DESI;

- World Digital Competitiveness Index - WDCI;

- ICT Development Index - IDI;

- Global Connectivity Index - GCI;

- Digital Evolution Index -DEI;

- Networked Readiness Index - NRI;

- E-Government Development Index - EGDI;

- Global Innovation Index - GII.

The index of digital economy and society is the most complex and modern. It assesses the global achievements of European countries in the field of information technology development and monitors their dynamics in five areas: communications, human capital, Internet use, digital integration, public digital services, each of which, in turn, includes indicators with a certain specific weight in their direction (a total of more than 40 indicators). Table. 1 shows the value of this index for 2017-2019 and the ratings of the European Union.

Table 1

Digital Economy and Society Index for EU countries in 2017-2019

\begin{tabular}{|l|c|c|c|c|c|c|}
\hline Country & $\begin{array}{c}\text { DESI } \\
\text { value } \\
(2017)\end{array}$ & Rank (2017) & $\begin{array}{c}\text { DESI } \\
\text { value } \\
(2018)\end{array}$ & Rank (2018) & $\begin{array}{c}\text { DESI } \\
\text { value } \\
(2019)\end{array}$ & Rank (2019) \\
\hline Austria & 49,2 & 12 & 51,9 & 12 & 53,9 & 13 \\
\hline Belgium & 55,2 & 7 & 56,6 & 9 & 59,4 & 9 \\
\hline Bulgaria & 32,4 & 27 & 35,5 & 26 & 36,2 & 28 \\
\hline Greece & 33,1 & 26 & 34,9 & 28 & 38,0 & 26 \\
\hline Denmark & 65,6 & 1 & 66,1 & 4 & 68,8 & 4 \\
\hline Estonia & 54,9 & 9 & 57,2 & 7 & 60,0 & 8 \\
\hline Ireland & 52,8 & 10 & 57,0 & 8 & 61,4 & 7 \\
\hline Italy & 36,5 & 24 & 38,9 & 24 & 43,9 & 24 \\
\hline Spain & 49,1 & 13 & 53,2 & 11 & 56,1 & 11 \\
\hline Cyprus & 40,5 & 22 & 43,2 & 22 & 45,8 & 22 \\
\hline Latvia & 43,1 & 19 & 46,9 & 18 & 50,0 & 17 \\
\hline Lithuania & 44,6 & 18 & 49,2 & 14 & 52,0 & 14 \\
\hline Luxemburg & 56,4 & 5 & 59,5 & 5 & 61,8 & 6 \\
\hline \hline
\end{tabular}




\begin{tabular}{|l|c|c|c|c|c|c|}
\hline Malta & 55,0 & 8 & 56,6 & 10 & 58,1 & 10 \\
\hline Netherlands & 63,5 & 3 & 66,8 & 2 & 68,9 & 3 \\
\hline Germany & 49,4 & 11 & 51,8 & 13 & 54,4 & 12 \\
\hline UK & 55,6 & 6 & 58,8 & 6 & 61,9 & 5 \\
\hline Poland & 36,1 & 25 & 38,8 & 25 & 41,6 & 25 \\
\hline Portugal & 44,6 & 17 & 46,8 & 19 & 49,2 & 19 \\
\hline Romania & 32,0 & 28 & 35,4 & 27 & 36,5 & 27 \\
\hline Slovakia & 41,0 & 21 & 44,5 & 20 & 46,3 & 21 \\
\hline Slovenia & 45,1 & 16 & 47,9 & 15 & 50,9 & 16 \\
\hline Hungary & 40,1 & 23 & 43,2 & 23 & 45,4 & 23 \\
\hline Finland & 63,7 & 2 & 66,3 & 3 & 69,9 & 1 \\
\hline France & 45,6 & 14 & 47,7 & 16 & 51,0 & 15 \\
\hline Croatia & 41,4 & 20 & 43,8 & 21 & 47,4 & 20 \\
\hline Czech & 45,3 & 15 & 47,6 & 17 & 50,0 & 18 \\
\hline Sweden & 63,2 & 4 & 66,9 & 1 & 69,5 & 2 \\
\hline EU & 46,9 & $\mathrm{x}$ & 49,8 & $\mathrm{x}$ & 52,5 & $\mathrm{x}$ \\
\hline
\end{tabular}

Source: formed by the authors on the basis of data from the European Commission [12]

According to the European Commission, which annually publishes the results of the Digital Economy and Society Index (DESI) and tracks the overall digital performance of Europe, it is clear that during 20172019, leadership positions among European countries have changed. Thus, the highest level of digitalization in 2017 was achieved by Denmark, in 2018 - Sweden and in 2019 - Finland. The lowest levels of digitization are in Bulgaria, Romania and Greece. For Ukraine, this indicator is not determined, as it is not a member of the European Union and there is no mechanism for compiling statistical information to calculate the index.

The values of individual components of the Digital Economy and Society Index in 2019 are shown in Figure 1.

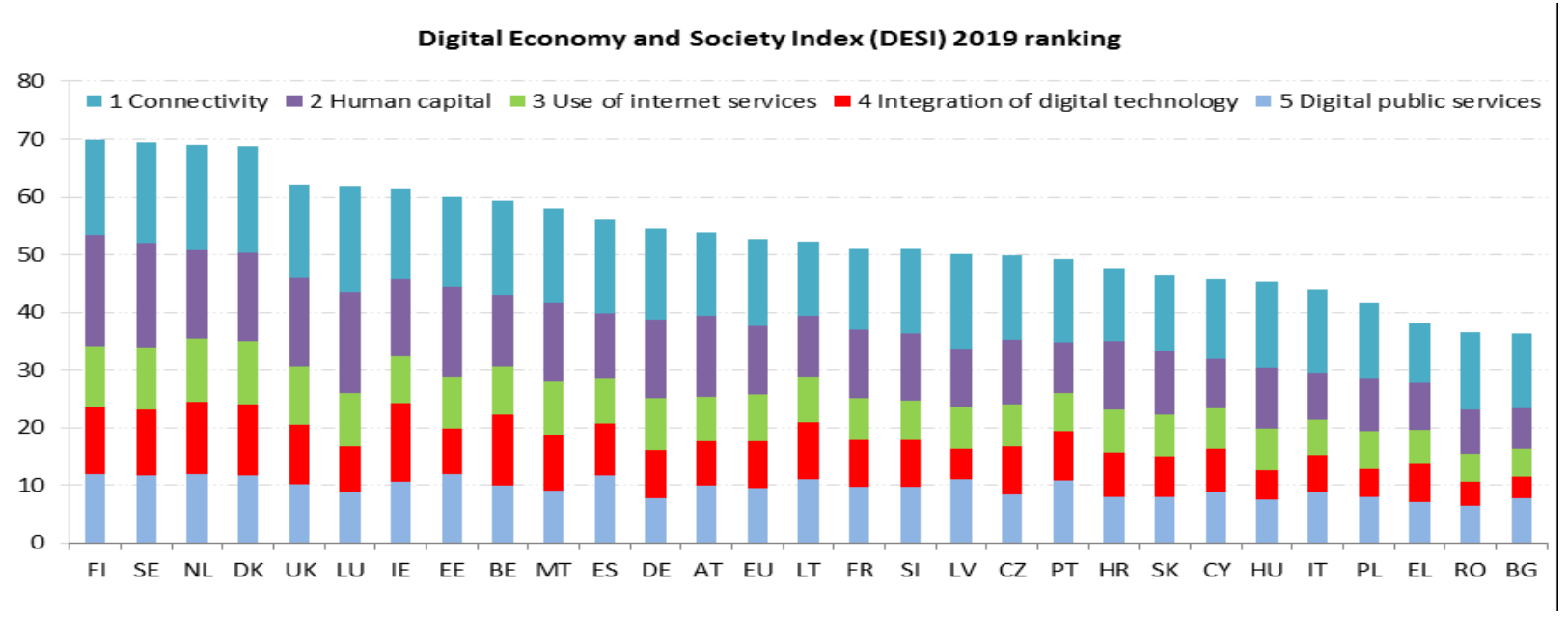

Figure 1. Digital Economy and Society Index (DESI) in 2019 for EU countries

Source: formed by the authors on the basis of data from the European Commission [12]

The total Internet audience in Ukraine (excluding Crimea) has grown to $66.1 \%$ and is 21.8 million users. These are the results of a study conducted by Factum Group Ukraine [13, p.102].

The central element on which the entire digital economy is built is information. And information is a special commodity (economic good), which takes the form of information products and services. In a digital economy, information, acting as the most valuable resource, is formed, stored, transmitted and processed using information and communication technologies. The development of the digital economy is associated with the development and implementation of new information and communication technologies in the activities of enterprises. 
S. M. Shkarlet and I. V. Sadchykova identify the following main advantages for the operation of the enterprise in the digital economy: the use of computer technology, software and hardware; introduction of innovations in business processes; operation of large arrays of information data; ensuring information protection; inflow of new investments; increase labor productivity; customer focus; speed and efficiency of any operations, etc. [14, p. 267].

However, along with the benefits of operating in a digital economy, there are threats that negatively affect the functioning of enterprises. Among such threats: violation of the confidentiality, integrity and availability of electronic information resources processed in communication and technological systems; unauthorized access to such resources; violation of the mode of operation of communication and technological systems; temporary reduction of labor productivity due to the introduction of new technologies; temporary growth of unevenness in the distribution of income for the period of advanced training, etc.

The development of the digital economy in the future will become more widespread, so it is important to quickly adapt the best practices of digital transformation to the development of Ukrainian business. Digital transformation allows the company to gain a set of unique competitive advantages and become more sustainable.

Active usage of the advantages of digitalization of economic activity requires the management of enterprises to focus on improving the existing or creating an effective system of financial and economic security, where special attention should be paid to ensuring its information component.

We consider financial and economic security of the enterprise in terms of digitalization as a protection of the enterprise from external and internal negative factors and the introduction of innovative information technologies and software for its stable and dynamic development.

The main directions of ensuring the financial and economic security of enterprises in the new realities of digitalization of economic activity:

- use of new computer technologies;

- ensuring uninterrupted and correct operation of the software;

- use of effective means of information protection;

- taking into account the positive aspects of digitalization of economic activity;

- accurate analysis of potential threats that may arise in the process of digitalization;

- development and implementation of new information innovations in the work of the enterprise;

- qualified operation of a large array of information data;

- introduction of new mechanisms to prevent threats and create reliable protection against them.

Thus, the development of the digital economy has both positive and negative impact on the activities of domestic enterprises. In the digital economy, companies widely used communication and information technologies, use Internet services to sell products, implement new mechanisms to prevent threats that may arise in the digitalization process, and create reliable protection against them, involving highly qualified professionals.

Conclusions and prospects for further research. Digitalization has become an integral part of the functioning of domestic enterprises. Therefore, it is important to quickly adapt the best practices of digital transformation to the development of domestic business.

Enterprises in the context of digitalization need to focus on improving the existing or creating an effective system of financial and economic security, where special attention should be paid to ensuring its information component.

\section{Sources and literature}

1. Tapscott D. The Digital Economy: Promise and Peril in the Age of Networked Intelligence. McGraw-Hill, 1994. $368 \mathrm{p}$.

2. Tapscott D. The Digital Economy anniversary edition: Rethinking Promise and Peril in the Age of Networked Intelligence. McGraw-Hill, 2014. 432 p.

3. Lane N. Advancing the Digital Economy into the 21st Century. Information Systems Frontiers. 1999. Vol. 1, no. 3. P. 317-320. DOI : https://doi.org/10.1023/A:1010010630396. 
4. Mesenbourg T. L. Measuring the Digital Economy. U.S. Bureau of the Census, Suitland, MD. 2001. URL : https://www.census.gov/content/dam/Census/library/working- papers/2001/econ/umdigital.pdf

5. Управление бизнесом в цифровой экономике: вызовы и решения : монография / под. ред. И. А. Аренкова, .Т. А. Лезиной, М. К. Ценжарик, Е. Г. Черновой. СПб. : Изд-во С.-Петерб. ун-та. 2019.360 с.

6. Веретюк С. М., Пілінський В. В. Визначення пріоритетних напрямків розвитку цифрової економіки в Україні. Наукові записки Украӥнського науково-дослідного інституту зв 'язку. 2016. № 2. С. 51-58.

7. Коляденко С. В. Цифрова економіка: передумови та етапи становлення в Україні і у світі. Економіка. Фінанси. Менеджмент. 2016. № 6. С. 106-107.

8. Апалькова В. В. Концепція розвитку цифрової економіки в Свросоюзі та перспективи України. Вісник Дніпропетровського університету. Серія : Менеджмент інновацій. 2015. Вип. 4. С. 9-18.

9. Чмерук Г. Г. Цифрова економіка як окремий сектор національної економіки держави. Науковий вісник Ужгородського національного університету. Серія: Міжнародні економічні відносини та світове господарство. 2019. Вип. 27, ч. 2. С. 92-97.

10. Про схвалення Концепції розвитку цифрової економіки та суспільства України на 2018-2020 роки та затвердження плану заходів щодо ऑiі реалізації. Розпорядження КМУ від 17.01.2018 p. № 67-3. URL : https://zakon.rada.gov.ua/laws/show/67-2018-\%D1\%80.

11. Аптекман А., Калабин В., Клинцов В. и др. Цифровая Россия: новая реальность. Mосква : Digital McKinsey, 2017. 133 c. URL : https://www.mckinsey.com.

12. Digital Economy and Society Index 2019 - Country Reporting. URL : https://ec.europa.eu/digital-singlemarket/en/news/digital-economy-and-society-index-desi-2019

13. Ліпич Л. Г. Зміна підходів до управління в епоху багатовекторного постіндустріального суспільства. Інтелект ХХІ. 2017. № 4. С. 99-103.

14. Шкарлет С., Садчикова I. Трансформація системи фінансово-економічної безпеки підприємства в умовах цифрової економіки. Проблеми і перспективи економіки і управління. 2019. № 3(19). С. $264-276$.

\section{References}

1. Tapscott D. (1994). The Digital Economy: Promise and Peril in the Age of Networked Intelligence. McGrawHill. - 368 p. [in English].

2. Tapscott D. (2014). The Digital Economy anniversary edition: Rethinking Promise and Peril in the Age of Networked Intelligence. McGraw-Hill. - 432 p. [in English].

3. Lane N. (1999). Advancing the Digital Economy into the 21st Century. Information Systems Frontiers. Vol. 1, no. 3. - P. 317-320. DOI : https://doi.org/10.1023/A:1010010630396 [in English].

4. Mesenbourg T. L. (2001). Measuring the Digital Economy. U.S. Bureau of the Census, Suitland, MD. URL : https://www.census.gov/content/dam/Census/library/working- papers/2001/econ/umdigital.pdf

5. Upravlenye byznesom v cyfrovoj эkonomyke: vyzovy y reshenyja (2019) [Business Management in the Digital Economy: Challenges and Solutions] : monoghrafyja / pod. red. Y. A. Arenkova, T. A. Lezynoj, M. K. Cenzharyk, E. Gh. Chernovoj. SPb. : Yzd-vo S.-Peterb. un-ta. - 360 s. [in Russian].

6. Veretjuk C. M., Pilinsjkyj V. V. (2016). Vyznachennja priorytetnykh naprjamkiv rozvytku cyfrovoji ekonomiky v Ukrajini [Identification of priority areas of digital economy development in Ukraine]. Naukovi zapysky Ukrajinsjkogho naukovo-doslidnogho instytutu zv'jazku, (2). - P. 51-58 [in Ukrainian].

7. Koljadenko S. V. (2016). Cyfrova ekonomika: peredumovy ta etapy stanovlennja v Ukrajini i u sviti [Digital economy: preconditions and stages of formation in Ukraine and in the world]. Ekonomika. Finansy. Menedzhment, (6). - P. 106-107 [in Ukrainian].

8. Apaljkova V. V. (2015). Koncepcija rozvytku cyfrovoji ekonomiky v Jevrosojuzi ta perspektyvy Ukrajiny [The concept of digital economy development in the European Union and prospects of Ukraine]. Visnyk Dnipropetrovsjkogho universytetu. Serija : Menedzhment innovacij, (4). - P. 9-18 [in Ukrainian].

9. Chmeruk Gh. Gh. (2019). Cyfrova ekonomika jak okremyj sektor nacionaljnoji ekonomiky derzhavy [Digital economy as a separate sector of the national economy]. Naukovyj visnyk Uzhghorodsjkogho nacionaljnogho universytetu. Serija: Mizhnarodni ekonomichni vidnosyny ta svitove ghospodarstvo, (27), (2). - P.92-97 [in Ukrainian].

10. Pro skhvalennja Koncepciji rozvytku cyfrovoji ekonomiky ta suspiljstva Ukrajiny na 2018-2020 roky ta zatverdzhennja planu zakhodiv shhodo jiji realizaciji [On approval of the Concept of development of the digital economy and society of Ukraine for 2018-2020 and approval of the action plan for its implementation]. Rozporjadzhennja KMU vid 17.01.2018 r. № 67-z. URL : https://zakon.rada.gov.ua/laws/show/67-2018-\%D1\%80 [in Ukrainian]. 
11. Aptekman A., Kalabyn V., Klyncov V. y dr. (2017). Cyfrovaja Rossyja: novaja realjnostj [Digital Russia: a new reality]. Moskva : Digital McKinsey, - 133. URL: https://www.mckinsey.com.

12. Digital Economy and Society Index 2019 - Country Reporting. URL : https://ec.europa.eu/digital-singlemarket/en/news/digital-economy-and-society-index-desi-2019 [in English].

13. Lipych L. Gh. (2017). Zmina pidkhodiv do upravlinnja v epokhu baghatovektornogho postindustrialjnogho suspiljstva [Changing approaches to governance in the era of multi-vector post-industrial society]. Intelekt XXI, (4). P. 99-103 [in Ukrainian].

14. Shkarlet S., Sadchykova I. Transformacija systemy finansovo-ekonomichnoji bezpeky pidpryjemstva $\mathrm{v}$ umovakh cyfrovoji ekonomiky [Transformation of the system of financial and economic security of the enterprise in the digital economy]. Problemy i perspektyvy ekonomiky i upravlinnja, (3(19)). - P. 264-276 [in Ukrainian].

Стаття надійшла до редакції 20.08.2020 р. 